PEDAGÓGUSKÉPZÉS, 10-11 (39-40), 2012-2013. 149-179.

\title{
A HOLLAND PEDAGÓGUSKÉPZŐK SZAKMAI SZTENDERDJEINEK 2012. ÉVI ÁTDOLGOZOTT VÁLTOZATÁRÓL
}

\section{Ko Melief - Martine VAN RIJSWIJK - ANKe TigchelaAR}

Snoek, Swennen és Klink (2011) a pedagógusképzők ${ }^{1}$ szakmai felkészültségéről és helyzetéről, valamint az Európában jelenleg folyó szakpolitikai vitáról írt összehasonlító tanulmányukban megállapítják, hogy mind Hollandiában, mind Magyarországon léteznek erős, a tanárképzőket tömörítő szakmai egyesületek. Mindkét országban érvényben vannak kifejezetten a képzőkre vonatkozó jogszabályok, és a tanárképzés minőségének ellenőrzéséért felelős állami szervek is müködnek. Továbbá mindkét országban történtek kezdeményezések egy, a pedagógusképzőket szolgáló gyakorlati tudásbázis létrehozására (Snoek, Swennen és Klink, 2011). Hollandiában az utóbbi kezdeményezés más egyebekkel együtt a holland tanárképzők szakmai egyesületének (VELON) egyik legjelentősebb törekvéséhez, a tanárképzők szakmai sztenderdjeinek kidolgozásához kapcsolódik. A jelen tanulmánynak kettős célja van: egyrészt bemutatni az imént említett „Holland pedagógusképzők szakmai sztenderdjei 2012" legújabb átdolgozásának eredményeit, másrészt betekintést nyújtani az ezzel összefüggő fejlesztési folyamatokba. Az átdolgozott 2012-es holland sztenderdek a jelen és a jövő tanárképzőire vonatkozó minőségi értékelés alapjául szolgálnak. A sztenderdek a szakmai alapelveit és négy kompetenciaterületet foglalnak magukba. Meghatározzák, hogy miben áll a tanárképzők szakmaisága, milyen kompetenciákkal rendelkezik a valamelyest már tapasztalt tanárképző, és munkájához milyen tudásanyagra van szüksége. A sztenderdek minden pedagógusképzőre vonatkoznak, függetlenül a munkahelyi környezettől, és attól, hogy milyen korcsoport vagy a tantárgyi terület számára képeznek pedagógusokat. A sztenderdekben megfogalmazódik, miben áll a pedagógusképzők szakmaisága, és melyek a képzők általános kompetenciái.

A sztenderdek kidolgozását a Holland Tanárképzők Egyesülete (VELON) kezdeményezte, és a holland kormány pénzügyi támogatásával valósult meg. A VELON, amelynek jelenleg 1500 tagja van, a múlt század 80-as éveiben alakult. A VELON megalakulásától kezdődően fontos feladatának tartotta, hogy erősítse mind az egyéni szakemberek, mind a szakmai közösség egészének professzionalizálódását. E célból a VELON számos kezdeményezést indított útjára az elmúlt két évtizedben. A múlt század 90-es éveinek végén kezdeményezte a holland pedagógusképzők szakmai sztenderdjeinek kidolgozását és ezzel párhuzamosan egy regisztrációs folyamat el-

\footnotetext{
${ }^{1}$ A pedagógusképző és tanárképző, pedagógusképzés és tanárképzés fogalmait felcserélhetően használjuk a cikkben.
} 
indítását. (Koster és Dengerink, 2001). A sztenderdek bevezetése óta a holland tanárképzőknek lehetőségük van arra, hogy kérjék a képzők névjegyzékébe történő felvételüket, amennyiben demonstrálni tudják, hogy munkájukat a szakmai sztenderdekben foglalt követelményeknek megfelelően végzik. A nyilvántartást a VELON megbízásából az SRL (Tanárképzők Névjegyzéke Alapítvány) gondozza.

Az utóbbi évtizedben a gyakorlóiskola intézményének bevezetése óta a munkahelyi tanulás egyre fontosabbá vált a tanárképzésben. Ezzel egyidejüleg nagymértékben megnőtt a gyakorlóiskolai képzők száma a tanárképzők csoportján belül. Ennek ellenére alig néhány gyakorlóiskolai képző - 136 regisztrált tanárképző közül mindössze 5 volt gyakorlóiskolai tanárképző - kérte a névjegyzékbe történő felvételét. Ezért a VELON létrehozott egy speciális „Képzés az iskolában” nevü szekciót, és kezdeményezte a szakmai sztenderdek megalkotását és a regisztrációs folyamat megindítását kifejezetten a gyakorlóiskolai tanárképzők számára (Melief, 2009a). Ez megkönnyítette a gyakorlóiskolai tanárképzők a regisztrációját, és a VELON is egyre jobban megismerkedett a tanárképzők Hollandiában viszonylag újnak számító csoportjával. A gyakorlóiskolai képzők sztenderdjeinek megalkotása óta megnövekedett a regisztrált gyakorlóiskolai tanárképzők száma: ma már az 514 regisztrált tanárképző közül 76 gyakorlóiskolai képző.

Az utóbbi időben a tanárképzés egyre inkább a tanárképző intézmények és a partneriskolák (gyakorlóiskolák és más partneriskolák) közös felelősségévé vált (Bergen és mtsai, 2009); a pedagógusképző felsőoktatási intézmények tanárképzői és a partneriskolákban dolgozó képzők team-ekben dolgoznak, így megosztják tudásukat, szakértelmüket. Az érintettek - maguk a szakemberek, a VELON és a szakpolitikusok egyaránt - úgy érezték, hogy olyan egységes sztenderdek kidolgozására van szükség, amely minden pedagógusképzőre vonatkozik, szakmai hátterüktől és munkahelyi környezetüktöl függetlenül. Ezért 2009-ben a VELON kezdeményezte a felsőoktatásban dolgozó tanárképzők és a partneriskolákban dolgozó tanárképzők sztenderdjeinek egyesítését és egységesítését a kapcsolódó regisztrációs eljárással együtt. Ez „A tanárképzők szakmai kompetenciái” nevü VELON-projekt részeként valósult meg. Az átdolgozott szakmai sztenderdek és a kapcsolódó regisztrációs eljárás első ízben biztosít keretet a pedagógusképzők számára a további professzionalizálódáshoz. Továbbá a sztenderdek vonatkoztatási rendszerként is szolgálhatnak a képzők teamjeinek szakmai továbbképzése során, és felhasználhatók az egyéni szakmai fejlődés orientálására is, akár kezdő, akár tapasztalt, akár felsőoktatásban, akár partneriskolában dolgozó képzők esetében. Az átdolgozott sztenderdek és a holland tanárképzői tudásbázis szoros összekapcsolása (Attema-Noorderwier és mtsai, 2012) újabb lehetőséget nyújt a minőségbiztosításra.

Az alábbi 1. részben a szakmai sztenderdek formáját és tartalmát tárgyaljuk. A 2. rész a sztenderdek funkcióit részletezi. A 3. rész tágabb (országos és nemzetközi) aspektusból tárgyalja a szakmai sztenderdeket. A 4. rész a szakmai sztenderdek megalkotásának folyamatát mutatja be. Az 5. szakasz részletesebben szól azok- 
ról a döntésekről, amelyeket a kidolgozás során meg kellett hozni. Végül a 6. szakasz a jövőbeli teendőket taglalja.

\section{A VELON szakmai sztenderdjei, 2012}

A VELON tanárképzési szakmai sztenderdjei a közepes tapasztalattal rendelkező tanárképzők kompetenciáinak fejlettségét írják le. A sztenderdek úgy készültek, hogy könnyen elérhetők legyenek a világhálón keresztül. A sztenderdekben pedagógusképzőnek minősül minden olyan személy, aki egyetemen vagy tanárképző felsőoktatási intézményben (a továbbiakban: intézményi tanárképző), vagy gyakorlóiskolában (a továbbiakban: iskolai tanárképző) dolgozik, és szervezett formában járul hozzá a leendő vagy már praktizáló pedagógusok képzéséhez (Swennen, 2012).

A modell középpontjában a szakmai alapelvek és négy, az alapelvekhez kapcsolódó kompetenciaterület áll. Ezeket a tanárképzésben dolgozó különböző szakemberek nézőpontjait megtestesítő kockák veszik körül (lásd a Függeléket). Ezek a nézőpontok nem képezik a szakmai sztenderdek részét. Az alábbiakban az alapelveket, a kompetenciaterületeket és a különböző nézőpontokat mutatjuk be, ebben a sorrendben.

\section{Az alapelvek}

A szakmai sztenderdek alapelvei (lásd a Függeléket) képezik a tanárképzők szakmai tevékenységének alapját. Ezek együttesen megtestesítik a tanárképzés szakmaiságát. Az alapelvek a tanárképzők három meghatározó tevékenységét a tanulás fogalmának segítségével ragadják meg: a tanulók tanulása, a (leendỏ) tanárok tanulása és maguknak a tanárképzőknek a tanulása (Koster és Dengerink, 2001; Snoek, Swennen és van der Valk, 2006). A tanárképzési professzió legfontosabb jellemzöje a másodrendủ tanítási tevékenység, (Murray és Male, 2005), ami azt jelenti, hogy a tanárképző olyan tanár, aki (leendő) tanárokat tanít, ezért munkája célzatosan és tudatosan modellül is szolgál a tanárjelöltek számára.

\section{A kompetenciaterületek}

A négy kompetenciaterület (lásd a Függeléket) azt mutatja be, hogy a tanárképzönek milyen kompetenciákkal kell rendelkeznie ahhoz, hogy szakmáját müvelje. Ezek a következők: „didaktikai kompetencia”, „a szakmai tanulás irányításának kompetenciája”, „szervezési és irányítási kompetencia” és „fejlesztési kompetencia”. Mindegyik kompetenciaterületnek megvan a maga leírása, és mindegyik további háromnégy részterületet foglal magába. A részterületek leírásai számos viselkedési indikátort tartalmaznak. A viselkedési indikátorok csupán illusztrációul szolgálnak, a teljesség igénye nélkül. Ezen kívül mindegyik kompetenciaterület leírása tartalmaz a tanárképzők tudásbázisából származó releváns irányított kérdéseket is, mivel a holland pedagógusképzési tudásbázis ilyen, úgynevezett irányított kérdések köré szervezö- 
dik. A kérdések összekötik a sztenderdeket és a tudásbázist. Az egyes kompetenciaterületek felépítése megfelel a bevett kompetenciadefinícióknak, amelyekre többnyire ugyanaz a hármas felosztás jellemző: attitüd, képességek, és tudás (Meriënboer, Klink és Hendriks, 2002).

\section{Nézőpontok}

Az átdolgozott szakmai sztenderdek hangsúlyosan minden tanárképzőre vonatkoznak, tekintet nélkül arra, hogy milyen munkahelyi kontextusban dolgoznak, mi a funkciójuk, milyen célcsoporttal foglalkoznak, vagy milyen (iskolai) tantárgyi területen dolgoznak. A szakmai sztenderdeket övező nézőpontok (lásd a Függeléket) lehetővé teszik, hogy a szakmai követelményeket különböző szerepek és munkahelyi környezetek szempontjából értelmezzük. Ezek a nézőpontok azonban kívül esnek a szorosan vett sztenderdeken, csak a sztenderdek jobb megértését és könnyebb felismerhetőségét szolgálják. A sztenderdeket a következő nézőpontok veszik körül: iskolai tanárképző, intézményi tanárképző, kutató, tantervfejlesztő, tantárgypedagógus tanárképző, tanártovábbképző és értékelő. Egy nézőpont helye üresen maradt, hogy lehetővé tegye egy további nézőpont bevezetését.

\section{A szakmai sztenderdek funkciója}

A VELON által megalkotott tanárképzési szakmai sztenderdek elsősorban világossá kívánják tenni a szakma természetét, és viszonyítási alapul kívánnak szolgálni a szakma egésze számára (Ingvarson, 1998). Másodsorban, a sztenderdek útmutatóul szolgálnak a tanárképzők szakmai fejlődése, fejlesztése, továbbképzése számára. Harmadsorban, a sztenderdek elérésének demonstrálása a szakmai névjegyzékbe történő felvétel feltétele. Az alábbiakban a VELON által megalkotott tanárképzési szakmai sztenderdek előbb említett három funkcióját részletezzük. Az azt követő (3.) részben pedig a sztenderdeket a tágabb nemzet(köz)i fejlemények kontextusában helyezzük el.

\section{A szakma természete}

A sztenderdek első funkciója a szakma természetének megvilágítása (Koster és mtsai, 2005; Lunenberg, Dengerink és Korthagen, 2013). Az alapelvek felvázolják a tanárképzők szakmai profilját, amely mértékadó viszonyítási alapul szolgálhat a tanárképzők szakmai közösségének további professzionalizálódása számára. A tanárképzők szakmai profiljának megrajzolása azért is fontos, mert a tanárképzési szakma erőteljesen fejlődik. A tanárképzés szakmaiságának megragadására irányuló kutatásban a tanárképzőket gyakran a tanárokhoz hasonlítják (például Smith, 2005). A legmeghatározóbb eltérés a tanárképzés és a tanítás között az „elsőrendü tanítás”, azaz a tanulók tanítása, és a „másodrendủ tanítás” közötti különbség (Murray és 
Male, 2005). A másodrendủ tanítás a tanulókat (majdan) tanító (leendő) tanárok tanítását és szupervízióját jelenti. Murray és Male (2005) szerint a másodrendủ tanítás a tanárképzési professzió jellemzője. További különbség a tanárok és tanárképzők között az, hogy a tanárképzők legalább baccalaureusi szinten oktatnak; így a tanárképzők és tanárok eltérő korosztályba tartozó diákokat tanítanak, és a tanárképzők olyan speciális pedagógiát alkalmaznak, az ún. modellezést, amelyben viselkedési példákat tárgyalnak meg és magyaráznak (Lunenberg, Korthagen és Swennen, 2007).

A sztenderdek második funkciója azzal függ össze, hogy a szakmai sztenderdek a szakmai fejlődés mércéjéül szolgálnak (Ingvarson, 1998; Smith, 2003). Az egyes kompetenciaterületek leírása azt mutatja meg, hogy milyen képességeket és attitüdöket várunk el a közepes tapasztalattal rendelkező pedagógustól. A kompetenciaterületek leírásai kiindulópontul szolgálhatnak az egyéni fejlesztési célok megfogalmazásához is. A tanárképzési tudásbázishoz való kapcsolódások lehetőséget nyújtanak a tanárképzőknek arra, hogy figyelmüket a releváns tudásforrásokra irányítsák. A szakmai sztenderdek továbbá segítik a tanárképzőket abban is, hogy elhelyezzék saját magukat a szakmán belül. Ezen kívül a sztenderdek szerepet játszhatnak a tanárképzők teamjeiben a kölcsönös együttmüködés, a team kompetenciák, a team célkitüzések és team professzionalizáció megvitatása során is. A sztenderdek felhasználásával fel lehet térképezni az egyén és a team erősségeit és fejlődési lehetőségeit egyaránt. A szakmai sztenderdek útmutatóul szolgálhatnak a pályakezdő tanárképzők és általában a tanárképzők szakmai fejlődését segítő programok és stratégiák kidolgozásához és strukturálásához is.

A tanárképzők szakmai sztenderdjeinek harmadik funkciója a szakmai névjegyzékbe való felvételhez kapcsolódik (Dengerink és mtsai, 2007). Amikor egy tanárképző első alkalommal kéri felvételét a tanárképzők névjegyzékébe, az első teendője az, hogy ismerje meg a sztenderdeket és nyilatkozzon, hogy egyetért-e velük. A szakmai névjegyzékbe történő felvételhez a kérelmezőnek át kell esnie a regisztrációs eljáráson, amelynek kulcselemét a szakmai sztenderdek adják. Egy portfólió segítségével öt ún. „munkán” vagy „,produktumon” keresztül kell bemutatnia, hogy a szakmai sztenderdben leírt közepes tapasztalattal rendelkező tanárképző szintjén végzi a munkáját. Az 1. táblázat a regisztrációs eljárás rövid leírását tartalmazza.

1. táblázat: A regisztrációs eljárás

\begin{tabular}{|c|l|}
\hline $\begin{array}{c}\text { Munkák/ } \\
\text { produktumok }\end{array}$ & \multicolumn{1}{c|}{ Rövid leírás } \\
\hline $\begin{array}{c}\text { 1. Formai } \\
\text { ellenőrzés }\end{array}$ & $\begin{array}{l}\text { A tanárképző ellenőrzi, hogy megfelel-e a formai követelményeknek: } \\
\text { jogosult-e a regisztrációra (rendelkezik-e a megfelelö kvalifikációval; } \\
\text { milyen tanárképzési tapasztalata van; melyek a jelenlegi feladatai). } \\
\text { A tanárképző megismerkedik a szakmai sztenderdekkel és egyetértése } \\
\text { jeléül aláírja azokat. }\end{array}$ \\
\hline
\end{tabular}




\begin{tabular}{|c|c|}
\hline $\begin{array}{c}\text { Munkák/ } \\
\text { produktumok }\end{array}$ & Rövid leírás \\
\hline 2. Önértékelés & $\begin{array}{l}\text { A tanárképző önértékelést ír az alábbi módon: } \\
\text { - kitölti a négy kompetenciaterületen alapuló strukturált kérdőívet, } \\
\text { amelyet } \\
\text { - rövid magyarázattal egészít ki. }\end{array}$ \\
\hline 3. Esetleírások & $\begin{array}{l}\text { A tanárképző bemutat két olyan fontos, valós helyzetet, amelyet } \\
\text { tanárképzőként átélt, és amelyek jól jellemzik a tevékenységét. } \\
\text { Legalább az egyik helyzetnek kapcsolódnia kell a „didaktikai” } \\
\text { vagy a „szakmai tanulás irányítása” kompetenciaterülethez. }\end{array}$ \\
\hline $\begin{array}{l}\text { 4. } 360 \text { fokos } \\
\text { visszacsatolás }\end{array}$ & $\begin{array}{l}\text { A tanárképző az önértékelő kérdőív felhasználásával visszacsatolást kér } \\
\text { hallgatóktól }(\mathrm{N}=10) \text { és kollégáitól vagy vezetőktől }(\mathrm{N}=5) \text {. } \\
\text { A tanárképző beszámol a visszajelzés eredményeiről és értelmezi azokat. }\end{array}$ \\
\hline $\begin{array}{l}\text { 5. Párbeszéd egy } \\
\text { kollégával }\end{array}$ & $\begin{array}{l}\text { A tanárképző megbeszéli az 1-4. munkákat/produktumokat egy olyan } \\
\text { kollégával, aki szintén felvételét kéri a tanárképzők szakmai névjegyzékébe. } \\
\text { A megbeszélés célja, hogy az egyéni fejlődésre vonatkozó gondolatokhoz } \\
\text { vezessen. A tanárképző beszámolót készít a beszélgetésről. }\end{array}$ \\
\hline $\begin{array}{l}\text { 6. Fejlesztési } \\
\text { terv }\end{array}$ & $\begin{array}{l}\text { A tanárképző egyéni fejlesztési tervet készít, amely tartalmazza } \\
\text { - az egyéni fejlesztési terv kitüzött irányát két konkrét cél megjelölésével, } \\
\text { - a megvalósítási tervet. }\end{array}$ \\
\hline Portfólió & $\begin{array}{l}\text { A tanárképző egy rövid bevezetővel ellátott portfólióba foglalja } \\
\text { a munkákat. }\end{array}$ \\
\hline
\end{tabular}

\section{A szakmai sztenderdek tágabb perspektívából}

Ebben a részben a szakmai sztenderdeket tágabb kontextusban elhelyezve értelmezzük.

\section{A tanárképzök nemzetközi sztenderdjei}

Európában már több mint 35 éve folynak a tanárképzőkre és a tanárképzés minőségére vonatkozó szakpolitikai kérdésekkel kapcsolatos nemzetközi kutatások az Európai Tanárképzők Egyesületének keretében. A pedagógusképzés minőségének fejlesztése kitüntetett jelentőségü kérdés Európában, és a szakmai sztenderdek kidolgozása ehhez járulhat hozzá (Dengerink és mtsai, 2007; Peer Learning Activity, 2010; Snoek, Swennen és van der Klink, 2011).Több országban is történt fontos elörelépés: a VELON megalkotta a holland szakmai sztenderdeket, a flamand tanárképzők egyesülete egy fejlesztési profilt dolgozott ki (VELOV, 2012), Ausztriában pedig elkezdődött a tanárképzők kompetenciáinak leírására irányuló munka (PLA, 2010). 
Európán kívül is történtek a tanárképzés minőségének és szakmaiságának fejlesztésére irányuló kezdeményezések. Az izraeli MOFET Intézet például feladatának tekinti a tanárképzési szakma professzionalizálását, illetve az egyes tanárképzők szakmai fejlesztését. Az Amerikai Tanárképzők Egyesületének szakmai sztenderdjei a pedagógusképzési programok alapjául szolgálnak, és a tanárképzők nemzetközi cseréjét, mobilitását is lehetővé teszik (Ben-Peretz és mtsai, 2010; Murray és $m t s a i, 2009)$. Ausztráliában a minőségellenőrzés területén kidolgozták a tanárképzési programok akkreditálásának részletes sztenderdjeit és eljárásait, igaz, az ausztrál sztenderdek az oktatási programokra, nem pedig egyéni tanárképzőkre vonatkoznak (AITSL, 2011; Jasman, 2003). Az ausztrálok a sztenderdek három kategóriáját különböztetik meg: a szakmai tudást, a szakmai magatartást és a szakmai elhivatottságot, amelyeket hét kompetenciaterületben részleteznek.

A 2. táblázat öt ország tanárképzőinek szakmai egyesületeit és azok tevékenységeit, valamint sztenderdjellegü eszközeit mutatja be. Az első három oszlop a flamand (a Flamand Tanárképzők Egyesületének fejlesztési profilja, VELOV), az amerikai (Amerikai Tanárképzők Egyesületének programja, ATE) és a holland (a VELON szakmai sztenderdjei) szakmai sztenderdeket mutatja be. A negyedik és ötödik oszlop az ausztrál tanárképzési programokra (Ausztrál Tanárképzési és Vezetőképző Intézet, AITSL) és az izraeli képzési programra (MOFET Intézet) vonatkozó információkat tartalmazzák. Így nemzetközi áttekintést kapunk azokról törekvésekről, amelyek célul tüzték ki a tanárképzés minőségének és szakmaiságának fejlesztését.

2. táblázat: Öt ország tanárképzőinek szakmai egyesületei és tevékenységük eleje

\begin{tabular}{|c|l|l|l|l|l|}
\hline & \multicolumn{1}{|c|}{$\begin{array}{c}\text { Belgium: } \\
\text { Flandria }\end{array}$} & \multicolumn{1}{|c|}{$\begin{array}{c}\text { Egyesült } \\
\text { Allamok }\end{array}$} & \multicolumn{1}{|c|}{ Hollandia } & \multicolumn{1}{|c|}{ Ausztrália } & \multicolumn{1}{|c|}{ Izrael } \\
\hline $\begin{array}{c}\text { 1. Szervezet } \\
+ \text { Forrás }\end{array}$ & $\begin{array}{l}\text { VELOV } \\
\text { (Flamand } \\
\text { Tanárképzők } \\
\text { Egyesülete), } \\
\text { 2012. }\end{array}$ & $\begin{array}{l}\text { ATE } \\
\text { (Tanárképzök } \\
\text { Egyesülete), } \\
2009^{3}\end{array}$ & $\begin{array}{l}\text { VELON } \\
\text { (Holland } \\
\text { Tanárképzők } \\
\text { Egyesülete), } \\
2012^{4}\end{array}$ & $\begin{array}{l}\text { AITSL (Ausztrál } \\
\text { Tanárképzési és } \\
\text { Iskolai } \\
\text { Vezetőképző } \\
\text { Intézet), 2011 }\end{array}$ & $\begin{array}{l}\text { MOFET } \\
\text { Intézet } \\
\text { Tanárképzési } \\
\text { kutatás, } \\
\text { tanterv- és } \\
\text { program- } \\
\text { fejlesztés }\end{array}$ \\
\hline
\end{tabular}

\footnotetext{
${ }^{2}$ www.lerarenopleiders-vlaanderen.be

${ }^{3}$ www.ate1.org

${ }^{4}$ www.velon.nl

${ }_{6}^{5}$ www.aitsl.edu.au

${ }^{6} \mathrm{http}: / /$ www.mofet.macam.ac.i1/eng/Pages/default.aspx
} 


\begin{tabular}{|c|c|c|c|c|c|}
\hline & $\begin{array}{l}\text { Belgium: } \\
\text { Flandria }\end{array}$ & $\begin{array}{l}\text { Egyesült } \\
\text { Államok }\end{array}$ & Hollandia & Ausztrália & Izrael \\
\hline $\begin{array}{l}\text { 2. Az eszköz } \\
\text { funkciója }\end{array}$ & $\begin{array}{l}\text { Vonatkoztatási } \\
\text { rendszer } \\
\text { a szakma } \\
\text { professzio- } \\
\text { nalizációja } \\
\text { számára } \\
\text { Szakmai } \\
\text { fejlesztési } \\
\text { útmutató }\end{array}$ & $\begin{array}{l}\text { Vonatkoztatási } \\
\text { rendszer } \\
\text { a szakma } \\
\text { professzio- } \\
\text { nalizációja } \\
\text { számára } \\
\text { Szakmai } \\
\text { fejlesztési } \\
\text { útmutató }\end{array}$ & $\begin{array}{l}\text { Vonatkoztatási } \\
\text { rendszer } \\
\text { a szakma } \\
\text { professzio- } \\
\text { nalizációja } \\
\text { számára } \\
\text { Szakmai } \\
\text { fejlesztési } \\
\text { útmutató } \\
\text { Benchmark } \\
\text { (viszonyítási } \\
\text { alap) a szakmai } \\
\text { közösség } \\
\text { minőség- } \\
\text { ellenőrzésére }\end{array}$ & $\begin{array}{l}\text { Vonatkoztatási } \\
\text { rendszer } \\
\text { a szakma } \\
\text { professzio- } \\
\text { nalizációja } \\
\text { számára } \\
\text { Benchmark } \\
\text { (viszonyítási } \\
\text { alap) képzési } \\
\text { programok } \\
\text { minőség- } \\
\text { ellenőrzésére }\end{array}$ & $\begin{array}{l}\text { Vonatkoztatási } \\
\text { rendszer } \\
\text { a szakma } \\
\text { professzio- } \\
\text { nalizációja } \\
\text { számára } \\
\text { Szakmai } \\
\text { fejlesztési } \\
\text { útmutató }\end{array}$ \\
\hline $\begin{array}{l}\text { 3. Forma és } \\
\text { tartalom }\end{array}$ & $\begin{array}{l}\text { Alapelvek } \\
\text { és kilenc, } \\
\text { a tudások, } \\
\text { képességek } \\
\text { és attitüdök } \\
\text { leírását } \\
\text { tartalmazó } \\
\text { kompetencia- } \\
\text { terület }\end{array}$ & \begin{tabular}{|l} 
Kilenc, \\
a magatartások \\
és teljesítmé- \\
nyek leírását \\
tartalmazó \\
kompetencia- \\
terület, megadva \\
a tudásforrások- \\
ra vonatkozó \\
utalásokat
\end{tabular} & $\begin{array}{l}\text { Alapelvek és } \\
\text { négy, a tudás } \\
\text { képességek és } \\
\text { attitüdök } \\
\text { leírását } \\
\text { tartalmazó } \\
\text { kompetencia- } \\
\text { terület. }\end{array}$ & $\begin{array}{l}\text { Hét intézményi } \\
\text { kompetenciát } \\
\text { tartalmazó három } \\
\text { terület, szervezeti } \\
\text { utasításokkal }\end{array}$ & $\begin{array}{l}\text { Az ATE } \\
\text { standardja elvi } \\
\text { kiindulópont- } \\
\text { ként szolgál } \\
\text { a képzési } \\
\text { program } \\
\text { számára. }\end{array}$ \\
\hline $\begin{array}{l}\text { 4. Regiszt- } \\
\text { ráció }\end{array}$ & Nincs & Nincs & $\begin{array}{l}\text { Van } \\
\text { (Egyéni } \\
\text { regisztráció } \\
\text { tanárképzők } \\
\text { számára) }\end{array}$ & $\begin{array}{l}\text { Van } \\
\text { (Tanárképzési } \\
\text { programok } \\
\text { számára) }\end{array}$ & Nincs \\
\hline
\end{tabular}

\section{A holland, a flamand és az amerikai szakmai sztenderdek összehasonlitása}

Ebben a részben három szempontból hasonlítjuk össze a VELON szakmai sztenderdjeit a flamand és az amerikai sztenderdekkel: a célcsoport, akikre a sztenderdek vonatkoznak, a sztenderdek célja, a sztenderdek formája és tartalma.

A VELON szakmai sztenderdjei a közepesen tapasztalt tanárképzők számára készültek, azaz olyan képzők számára, akik csupán minimális, hároméves tanárképzési tapasztalattal rendelkeznek. A sztenderd a szakma minden müvelőjére érvényes. 
Ugyanez mondható el az ATE szakmai sztenderdjeiről és a flamand fejlesztési profilról is. Flandriában a sztenderdek tanárképző teamekre is vonatkoznak, a teamek szakmai fejlödését szolgáló irányelvekként is müködnek.

Mind az amerikai szakmai sztenderdeknek, mind a flamand fejlesztési profilnak az a rendeltetése, hogy egyaránt szolgálja az egész szakma professzionalizálódását és az egyéni tanárképző szakmai fejlődését. A „professzionalizálódás” fogalma egy (új) szakma kialakulását jelenti, jelen esetben a pedagógusképzésben dolgozók értelmiségi szakmává alakulását. A „szakmai fejlődés” fogalma pedig a szakmában dolgozó egyén fejlődésére vonatkozik (Koster, 2002; Kallenberg, 2004). E kettős célon túl, a VELON szakmai sztenderdjeinek az is feladata, hogy lehetővé tegye a tanárképzők szakmai regisztrációját.

A VELON szakmai sztenderdjei néhány alapelvből és négy, ezekhez kapcsolódó kompetenciaterületből állnak. Minden egyes kompetenciaterülethez tartozik egy leírás, néhány viselkedési indikátor és egy tudáskomponens, amely hivatkozásokat tartalmaz a tanárképzők számára készült tudásbázis releváns elemeire (AttemaNoorderwier és mtsai, 2012). A flamand fejlesztési irányelvrendszer néhány alapelvből és kilenc kompetenciaterületből áll. Minden egyes kompetenciaterület tartalmazza a vonatkozó tudások, képességek és attitüdök leírását, ebben a sorrendben. $\mathrm{Az}$ amerikai sztenderdek kilenc rész-sztenderdből állnak. Minden egyes rész-sztenderd tartalmazza a tanárképzők képességeinek és attitüdbeli tulajdonságainak leírását, tartalmaz számos viselkedési indikátort és illusztrációs példaanyagot, valamint tudásforrásokra vonatkozó hivatkozásokat.

\section{Más szakmai közösségek szakmai sztenderdjei}

A VELON szakmai sztenderdjeinek továbbfejlesztése során a sztenderdeket összevetették Hollandián belül számos más szakma sztenderdjeivel, illetve egy esetben külföldi tanárképzési szakmai sztenderdekkel.

Hollandiában az egészségügyi dolgozók szakmai minőségét az egyéni egészségügyi szolgáltatás területén müködő szakmákra vonatkozó $\mathrm{BIG}^{7}$ törvény szabályozza. Az állam nyolc egészségügyi szakma számára írta elő a BIG-regisztrációt. A regisztrációhoz az egészségügyben dolgozóknak igazolniuk kell, hogy engedéllyel és megfelelő szakmai tapasztalattal rendelkeznek, és hogy karbantartják szakmai tudásukat és kompetenciáikat. A regisztráció és rendszeres megújítása az elöfeltétele annak, hogy a nyolc egészségügyi szakma valamelyikében bárki praktizálhasson.

Kanadában a Királyi Orvosi és Sebészeti Kollégium dolgozta ki a CanMeds Physician Competency Framework (Kanadai Orvosi Kompetenciarendszer) elnevezésủ sztenderdeket az orvosi szakma számára (Royal College, 2005). A sztenderdeket a szakmában hivatalosan elfogadott követelményrendszernek tekintik. A szten-

\footnotetext{
${ }^{7}$ http://www.rijksoverheid.nl/onderwerpen/kwaliteit-van-de-zorg/registratie-medische-beroepen
} 
derdek hét szerepet különböztetnek meg és definiálnak. E hét szerep minden az egészségügyben dolgozó szakemberre vonatkozik. A szerepleírások tartalmazzák, hogy az egészségügyi dolgozóknak milyen tudásokkal és attitüdökkel kell rendelkezniük a megfelelő betegellátáshoz. A CanMeds sztenderdek képezik a különböző akkreditációs folyamatok alapját is. Ezenkívül oktatási keretrendszerül is szolgálnak, és így képzési és továbbképzési programok alapját képezik.

2005-ben a Holland Királyi Egyesület az Orvostudomány Fejlődésének Előmozdításáért (KNMG - Koninklijke Nederlandsche Maatschappij tot bevordering van de Geneeskunst) a CanMeds mintájára alkotta meg szakmai sztenderdjeit az egészségügyben dolgozó szakemberek számára. ${ }^{8}$

A BIG-névjegyzék által lefedett nyolc szakmai közösséghez hasonlóan a holland mentősök szakmai szervezetei is kidolgozták a maguk szakmai regisztrációs követelményeit. ${ }^{9}$ E névjegyzéknek is az a célja, hogy garantálja a szakmai munka minőségét. A regisztrációs rendszer azt mutatja, hogy az adott szakma foglalkoztatottjai megfelelnek az előírt képzettségbeli követelményeknek, rendelkeznek a szükséges tapasztalattal, és karbantartják szakértelmüket.

Hollandiában az egészségügyi szektoron túl más szakmák művelői is megalkották a maguk sztenderdjeit. Egyes szakmák esetében a szakmai sztenderdek elsősorban a minőségellenőrzést szolgálják. Ha a szakmai sztenderdek elsősorban a minőségellenőrzést hivatottak szolgálni, akkor azt írják le, mi tekinthető jó szakmai gyakorlatnak. Sok esetben egyfajta regisztráció vagy akkreditáció is kapcsolódik a szakmai sztenderdekhez. Ilyen sztenderdeket alkottak a szervezeti tanácsadók, ${ }^{10}$ a humánerőforrás szakemberek, ${ }^{11}$ az építészek, ${ }^{12}$ az iskolavezetők ${ }^{13}$ és a régészek ${ }^{14}$.

Más szakmai egyesületek a szakmai fejlődést támogató vonatkoztatási keretrendszerként használják szakmai sztenderdjeiket. Az ilyen sztenderdek útmutatást nyújtó dokumentumok, amelyek a szakmai gyakorlati munka és a szakmán belüli dialógus támogatását szolgálják. Ilyen sztenderdeket alkottak a coachok ${ }^{15}$ és a belső ellenőrök ${ }^{16}$.

A különböző hollandiai szakmai szervezetek sztenderdjeinek áttekintése és a tanárképzőkre vonatkozó nemzetközi sztenderdek összehasonlítása után születtek meg

\footnotetext{
${ }^{8} \mathrm{http} / / / \mathrm{knmg}$.artsennet.nl/Publicaties/KNMGpublicatie/Algemene-competenties-van-de-medischspecialist-2005.htm

${ }^{9}$ Mentősök minöségügyi névjegyzéke, 2010

${ }^{10}$ Szervezeti szakértők és tanácsadók viselkedési kódexe. Ooa/ROA, 1997

${ }^{11}$ Humánerőforrás szakemberek viselkedési kódexe. Nvo2

12 Építészek viselkedési szabályai. BNA, 2006

${ }^{13}$ Iskolai vezetők szakmai sztenderdjei. Dutch Academy for School leaders (NSA), 2012

${ }^{14}$ Régészek etikai kódexe. Holland régészeti egyesület (NvvA), 2011 (Jelenleg nincs használatban a szakmán belül. Átdolgozás alatt.)

${ }^{15}$ Coachok viselkedési kódexe. Holland hivatásos coachok rendje (NOBCO)

${ }^{16}$ Belső ellenőrök szakmai sztenderdjei (Lbib, 2010)
} 
a VELON tanárképzési szakmai sztenderdjeinek átdolgozásával kapcsolatos döntések. A következő részekben a fejlesztési folyamatot és a fejlesztéssel kapcsolatos döntéseket mutatjuk be.

\section{A szakmai sztenderdek kidolgozása}

Fontos, hogy egy szakma sztenderdjei tükrözzék az adott szakmai közösség igényeit és céljait (Snoek és mtsai, 2011), és hogy összhangban legyenek azzal, amit a szakma müvelői fontosnak tartanak munkájukkal kapcsolatban. (Dengerink és $m t s a i, 2007)$. A sztenderdek megalkotása önmagában is elősegítheti a kidolgozó szakmai közösség professzionalizálódását (Dengerink és mtsai, 2007). A VELON számára ezek voltak a szakmai sztenderdek kidolgozásának alapelvei.

A szakmai sztenderdek kidolgozásának céljait egy viszonylag nagyarányú előzetes felmérés alapján határozták meg. Ez magába foglalt egyebek között egy, a VELON tagjaira kiterjedő kérdőíves adatgyüjtést és három munkakonferencián folytatott elemző beszélgetéseket a szakmai közösség tagjainak részvételével. Ezenkívül, a 2009. évi tavaszi VELON konferencián a tervbe vett átdolgozással külön workshop foglalkozott. A „Tanárképzők szakmai kompetenciái” nevủ munkacsoport (Melief, 2009a; Melief, 2009b) ilyen kiterjedt előzetes vizsgálatok után fogott hozzá a szakmai sztenderdek átdolgozásához.

\section{A fejlesztö csoport}

A munkacsoport a szakma különbözö területeinek tizenegy képviselőjéből álló fejlesztő csoportot hozott létre. A csoport reprezentatív jellegét a változatos összetétel garantálta: intézményi tanárképzők az általános és középiskolai (föiskolai, illetve egyetemi) tanárképzésből, gyakorlóiskolai/partneriskolai tanárképzők az általános és középiskolai (föiskolai, illetve egyetemi) tanárképzésből, föiskolai és egyetemi kutatók valamint szakértők egyaránt képviseltették magukat a csoportban. A csoport hét alkalommal ülésezett, és a munkacsoporttal együtt kritikusan gondolkodva tette meg szövegszerü, illetve a felépítésre és a struktúrára vonatkozó javaslatait, visszajelzésekkel szolgált az elkészült változatokra vonatkozóan, és részt vett a szakma sztenderdekkel kapcsolatban felmerült kérdéseivel foglalkozó kongresszusok és szakmai tanácskozások munkájában.

\section{A szakirodalom tanulmányozása}

A munkacsoport tanulmányozta a rendelkezésre álló szakirodalmat is. Összehasonlította a nemzetközi viszonylatban ismert, a tanárképzőkre vonatkozó szakmai sztenderdeket, megvizsgálta más hollandiai szakmai szervezetek sztenderdjeit, és tanulmányozta a tanárképzőkkel, a tanárképzéssel és a szakmai sztenderdekkel kapcsolatos nemzetközi szakirodalmat. 


\section{A munkafolyamat}

A szakmai sztenderdek funkciója és a projekt céljai alapján lefektették a szakmai sztenderdek felépítésére és átdolgozására vonatkozó alapelveket. Ezekből az alapelvekből kiindulva elkészültek az első változatok. A fejlesztő csoport tagjai tanácsadói feladatokat láttak el. A 2011 márciusában megrendezett VELON kongresszuson a munkacsoport bemutatta a sztenderdek első változatát a szakmai közösségnek. A kongresszuson felmerült javaslatokat beépítették a második változatba, amelyet egy 2011. évi decemberi munkakonferencián mutattak be a szakmai közösség képviselöinek. Majd a sztenderdek érvényességének további vizsgálatára került sor úgy terepen, mint szakértőkkel folytatott konzultációk során, a sztenderdek felépítésével, struktúrájával és szövegszerü tartalmával kapcsolatban. A pontosításra és javításra vonatkozó további javaslatokat is feldolgozták és beépítették a harmadik változatba, amelyet a 2012. évi VELOV/VELON kongresszus keretében szervezett szimpóziumon bocsátottak a szakmai közösség elé, amely ezt a változatot el is fogadta.

\section{A VELON szakmai sztenderdjeinek fejlesztése során meghozott döntések}

A jelen szakaszban néhány olyan döntést tárgyalunk, amelyek hatással voltak a szakmai sztenderdek formájára és tartalmára egyaránt.

\section{Az alapelvek kulcsszerepe}

Az alapelveknek központi jelentőségük van a szakmai sztenderdekben. Ezek az alapelvek jelenítik meg a tanárképzési professzió sajátosságait. Az alapelvek kidolgozásával valósult meg a szakmai sztenderdek azon célja, hogy a sztenderdek jelenítsék meg a tanárképzési professzió természetét, és így nyújtsanak támpontot a pedagógusképzés távlati koncepciójának kialakításához és az ezzel kapcsolatos szakmai diskurzushoz. Ezért született az a döntés az alapelvek megfogalmazásával kapcsolatban, hogy jelenjen meg bennük a tanárképzők alapvető attitüdjeinek kimerítő leírása. Az alapelvek rendeltetése nem az, hogy kötelező vagy normatív elöírásokként, hanem hogy nyitott keretül szolgáljanak.

\section{A tanárképzés megosztott szintere és felelössége}

A tanárképzés a felsőoktatási intézmények és a partneriskolák közös felelössége (Bergen és mtsai, 2009). A szakmai sztenderdek kidolgozása során az oktatási környezettel kapcsolatban a megosztott tanárképzés mellett döntöttek, elsősorban az utóbbi évtizedben a tanárképző intézményekben végbement változások következtében. A kutatási eredmények ugyanis azt mutatják, hogy a jó tanárképzés számára elengedhetetlen a tanárképző intézmények és az iskolák közötti együttmüködés 
(Velzen és Volman, 2009). A megosztott tanárképzés melletti döntés nem egy bizonyos megosztott képzési modell melletti döntést jelent (Maandag és mtsai, 2007; Geldens, 2007). A tanárképzők számára a megosztott képzés megszervezéséhez szükséges attitüd és kompetenciák szervesen beépültek a sztenderdek egészébe. Például a „szervezési és irányítási kompetenciaterület” azt írja le, hogy mit tehet egy tanárképző a tanárképző intézmény és az iskola közötti együttműködés strukturálása érdekében a megosztott tanárképzés keretei között. Például: „A tanárképző a legjobb tudása szerint kezdeményezi a tanárképző intézményben és az iskolában dolgozó tanárképzők közötti tartalmi koordináció megszervezését."

\section{A kompetenciaterületek betekintetést engednek a tanárképzök gyakorlati tevékenységébe}

Minden egyes kompetenciaterülethez a következő három definiált elem tartozik: attitüd (magának a kompetenciaterületnek a leírásában), kompetenciák (képességek) (a leírásban és a viselkedési indikátorokban) és tudás (a tudásbázis releváns irányított kérdéseire utaló hivatkozásokban). Ez összhangban van a kompetencia hasonló hármasságot mutató bevett definícióival (Meriënboer és mtsai, 2002).

Négy kompetenciaterületet választottak ki, amelyek jellemzőek a tanárképzők munkájára: „didaktikai kompetencia”, ,a szakmai tanulás irányításának kompetenciája”, „szervezési és irányítási kompetencia” és „fejlesztési kompetencia”. Amenynyire lehetséges volt, kerülték a kompetenciaterületek közötti átfedéseket.

A második kompetenciaterület ,a szakmai tanulás irányításának kompetenciája” nevet kapta, mert ez a kompetencia felnőttek tanulásának szupervíziójára és monitorozására vonatkozik (Murray és mtsai, 2009). E terület részletes kifejtése a szakmai tanulásirányítási kompetenciák és az interperszonális kompetenciák leírását tartalmazza. A szakmai tanulásirányítási kompetenciákat kifejtő részben például ezt mondja a tanárképzőről: „Interperszonális kompetenciával rendelkezik. Elősegíti a közte és a tanár(jelölt) között megvalósuló kommunikációt, illetve a (leendő) tanárok egymás közötti kommunikációját, új médiumok alkalmazásával is." Illetve: „Saját cselekvéseit össze tudja kapcsolni a (leendö) tanárok tanítási cselekvéseivel.”

\section{A tanárképzök gyakorlati munkájának elméleti támogatása}

A rendszer a tanárképzők gyakorlati munkájának elméleti támogatását a tanárképzési tudásbázisra való hivatkozásokkal valósítja meg. A tanárképzők konkrét releváns elméleti forrásokra vonatkozó utalásokat kapnak. A tanárképzési tudásbázis különösen alkalmas erre, mert nem csak elméleti meggondolásokat, hanem gyakorlati példákat és reflexiókat is tartalmaz. A kutatómunkát, illetve mások kutatómunkájának irányítását az alapelvek és a kompetenciaterületek a tanárképzési profeszszió egyik alkotóelemeként jellemzik (Loughran, 2005). 
A tanárképző kutatási kompetenciáinak definícióját a „fejlesztési kompetenciaterület”, a (leendő) tanárok (gyakorlati) kutatásának irányítási kompetenciáját pedig a „didaktikai kompetenciaterület” tartalmazza.

A szakmai sztenderdek szerint a tanárképzőnek képesnek kell lennie arra, hogy elemzően és kritikusan reflektáljon saját tevékenységére és a tanárképzés pedagógiai gyakorlatára: „A tanárképző elemzően közelít saját munkájához. Kritikusan és különböző elméleti nézőpontokból követi az oktatás új fejleményeit. A tanárképzési tudásbázist és a (gyakorlati) kutatás más eredményeit felhasználva valósítja meg és fejleszti tovább saját gyakorlati pedagógiai tevékenységét."

\section{A változatosság méltánylása}

Az átdolgozott szakmai sztenderdek generikusak, azaz bármely tanárképzőre érvényesek, tekintet nélkül a konkrét feladatokra, szerepekre vagy a munkahelyi környezetre. A konkrét feladatok, szerepek és az adott munkahelyi környezet befolyásolhatja, hogy egy bizonyos tanárképző hogyan valósítja meg vagy juttatja kifejezésre az egyes kompetenciaterületeket. Más szóval, az egyes tanárképzők konkrét feladatainak, szerepeinek és adott környezetének függvényében a különböző kompetenciák eltérő, kisebb vagy nagyobb hangsúlyt kapnak, illetve eltérő módon nyilvánulhatnak meg.

A feladatok, szerepek és a munkahelyi környezet tekintetében mutatkozó változatosságot a különféle nézőpontok szerepeltetése jeleníti meg. A sematikus modellben ezek veszik körül a szakmai sztenderdeket, ami azt fejezi ki, hogy a különböző nézőpontok befolyásolják az egyes kompetenciaterületek megvalósulását és kifejeződését. Ezeket a nézőpontokat a fejlesztési csoport által végzett munka, illetve a tanárképzés szakmai sztenderdjeinek fejlesztése során kapott visszajelzések alapján választották ki. Minden egyes nézőponthoz tartozik egy, az illető nézőpont természetére és a hozzá kapcsolódó tevékenységekre vonatkozó rövid leírás.

A nézőpontok periférikus feltüntetésével kiegészített, de egyébként generikus szakmai sztemderdek melletti döntés lehetővé tette a kidolgozásbeli differenciálás minimalizálását. Ez a döntés egyenes következménye a terepen mutatkozó igényeknek. A terepen dolgozó tanárképzők a konkrét adaptációkkal kapcsolatos (a fejlesztő csoportban, a terepen folytatott konzultációk alkalmával, konferenciákon és munkamegbeszéléseken elhangzott) megjegyzéseikben azt az igényt juttatták kifejezésre, hogy inkább a szakma olyan jellemző aspektusaira kíváncsiak, amelyek minden tanárképzőre vonatkoznak, semmint a különböző tanárképzők közötti különbségek hosszas elemzésére.

A nézőpontok nem részei maguknak a szakmai sztenderdeknek, hanem inkább iránymutatók. Egy adott nézőpont kidolgozása és a hozzá kapcsolódó tevékenységek részletezése maguknak a tanárképzőknek a feladata. E kategorizálás lehetővé teszi a tanárképzők számára, hogy maguk dolgozzák ki a saját feladataik, szerepeik 
és környezetük leírását, illetve azt, hogy az adott nézőpont milyen módon befolyásolja a szakmai sztenderdek értelmezését.

A szakértelem különböző fejlettségi szintjeinek megfelelő differenciálás a szakmai névjegyzéken belüli kategóriákban valósul meg. Ezek a kategóriák a következök: a leendő tanárképzők névjegyzéke, a szakmai névjegyzék és az újra-regisztráció. A vonatkozó eljárások jelzik a regisztráló személy szakértelmének szintjét, valamint azt, hogy a jelölt hogyan értékeli saját kompetenciáit a szakmai sztenderdek alapján. A különböző kompetencia fejlettségi szintek szerinti kategorizálás lehetöségét elvetették, mert az ilyen értékelési táblázatok használata elsősorban oktatási környezetekben szokásos (Jonsson és Svingby, 2007). Az egyetlen kivétel a regisztrációs eljárás során a $360^{\circ}$-os visszacsatolásban alkalmazott egyszerü táblázatos megoldás.

\section{A szakma dinamikájának vizuális megjelenitése}

A webes formátum választásával a szakmai sztenderdek interaktív módon jelennek meg. A modell azt mutatja, hogy az alapelvek kulcsszerepet játszanak a tanárképzői szakmában, és hogy a négy kompetenciaterület a sztenderdek részét képezik. A nézőpontok a modell körül helyezkednek el. A modell egy-egy elemére kattintva a modell mélyebb rétegeibe nyerünk betekintést. Így minden érdeklődő kiválaszthatja, hogy miről akar részletesebben olvasni.

Ezen a felületen egy tanárképző intézmény vezetésének tagja vagy egy iskolaigazgató, aki azt tervezi, hogy iskolájával részt kíván venni a tanárképzésben, tájékozódhat afelől, hogy mit várhat el egy tanárképzőtől. Az ilyen érdeklödő kezdetben másra kíváncsi, mint az a kezdő tanárképző, aki többet szeretne tudni a (leendő) tanárok szakmai tanulási folyamatának irányításával és monitorozásával kapcsolatos elméleti forrásokról. A modellben egyre mélyebbre haladva a felhasználó hozzájuthat ahhoz az információhoz, amely őt a tanárképzés mesterségével kapcsolatban leginkább érdekli. A szakmai sztenderdek felépítése lehetetlenné teszi hosszú kompetencia vagy viselkedési indikátor listák megjelenítését.

Végül, a webes megjelenítés dinamikus hozzáférést biztosít a tudásbázishoz. A tanárképzési szakma folyamatos átalakulásban van, ezért a tudásbázis is folyamatosan fejlődik. A szakmai sztenderdek webes szerkezete lehetővé teszi, hogy a tudásbázist folyamatosan bővítsék és így a tanárképzők számára biztosítsák a hozzáférést a legújabb eredményekhez.

\section{Jövőbeli teendők}

A holland tanárképzők új „VELON szakmai sztenderdjei 2012” minden tanárképzőre egyaránt vonatkoznak, függetlenül a (munkahelyi) környezettől, a célcsoporttól és a tantárgyi területtől. A szakmai sztenderdek alapjául szolgáló képzési kon- 
textus a tanárképző intézmények és partneriskoláik közötti együttmüködésen alapuló osztott tanárképzés. A tanárképzők szakma sztenderdjei elsősorban a szakma természetét szeretnék megvilágítani, és viszonyítási alapul kívánnak szolgálni a szakma egésze számára. Másodsorban, a sztenderdek útmutatóul szolgálnak a tanárképzők (egyéni és közösségi) szakmai fejlődése számára. Harmadrészt, a sztenderdek alkotják a szakmai regisztráció feltételéül szolgáló viszonyítási alapot. Ezek alapján a továbblépésnek három kulcseleme rajzolódik ki: a pályakezdés szakmai támogatása, a team regisztráció és a teamek szakmai fejlesztése.

A kezdő tanárképzők vonatkozásában, az átdolgozott 2012-es sztenderdeket integrálni lehetne egy, a pályakezdőket támogató program kialakításába, illetve továbbfejlesztésébe. A sztenderdek tájékozódási pontként szolgálhatnak a kezdő tanárképzők számára az új szakmájukba való belépés utáni átmeneti szakaszban. Mostanáig kevés kezdeményezés történt Hollandiában arra, hogy integrálják a pályakezdőket segítő programokat, a szakmai sztenderdeket és a tanárképzési tudásbázist. Ezek is többnyire helyi kezdeményezések voltak. A jövőben a VELON arra törekszik, hogy kidolgozzon egy, a pályakezdő tanárképzők munkáját segítő, a sztenderdek alapelveire épülö nemzeti programot.

A regisztrációt illetően egy fontos új lehetőség merült fel az utóbbi két év során. Korábban a regisztráció elsősorban az egyes tanárképzők egyéni kezdeményezésén alapult. Az új sztenderdek alapvető jellemzőjével, a megosztott képzéssel összhangban, „A professzionális tanárképzők ereje” nevü VELON csoport új programot kidolgozott ki a team regisztráció számára, amely lehetővé teszi, hogy az intézményi tanárképzők és az iskolai tanárképzők egy teamként regisztrálják magukat. Az első kísérletek ígéretesnek bizonyultak. Ugyanez érvényes a tanárképzők heterogén teamjeinek szakmai fejlődésére is, amelyben a sztenderdek egyaránt támpontul szolgálhatnak az egyéni szakmai fejlődés és a team professzionalizáció számára. Összességében elmondhatjuk, hogy a „VELON szakmai sztenderdek 2012” fontos szerepet tölt be a szakemberek, a képzők testületei és az oktatáspolitika közötti összjátékban.

\section{Irodalom}

AITSL (2011): Accreditation of initial teacher education programs in Australia: standards and procedures. Retrieved May 22, 2012 from http://www.aitsl.edu.au/verve/_resources/Accreditation_of_initial_teacher_education.pdf

Attema-Noorderwier, S. - Lunenberg, M. - Dengerink, J. - Korthagen, F. (2012): Relevantie en nut van de kennisbasis voor lerarenopleiders (Relevance and usefulness of the knowledge base for teacher educators). VELON-Tijdschrift voor lerarenopleiders, 33 (2), 4-11.

Ben-Perets, M. S. - Reichenberg, R. - Shimoni, S. (2010): Educators of educators: their goals, perceptions and practices. Professional Development in Education $36(1 / 2)$, $111-129$. 
Bergen, T. - Melief, K. - Beijaard, D. - Buitink, J. - Meijer, P. - Veen, K. van (red.) (2009): Perspectieven op samen leraren opleiden (Perspectives on jointly educating teachers). Antwerpen/Apeldoorn, Garant.

Dengerink, J. - Koster, B. - Lunenberg, M. - Korthagen, F. (2007): Lerarenopleiders maken werk van hun professionele ontwikkeling (Teacher educators focusing on their professional development). VELON-Tijdschrift voor lerarenopleiders, 28 (1), 32-37.

Jasman, A. (2003): Initial Teacher Education: Changing Curriculum, Pedagogies and Assessment. Change: Transformations in Education, 6 (2), 1-22.

Ingvarson, L. (1998): Professional development as the pursuit of professional standards: the standards-based professional development system. Teaching and Teacher Education, 14 (1), 127-140.

Jonsson, A. - Svingby, G. (2007): The use of scoring rubrics: Reliability, validity and educational consequences. Educational Research Review 2, 130-144.

Kallenberg, A. (2004): Tussen opleiden en professionele ontwikkeling: leren (en) organiseren van nieuwe leerarrangementen (Between teacher education and professional development: learning (and) organizing innovative learning arrangements). Lectorale rede. Leiden: Hogeschool Leiden.

Koster, B. (2002): Lerarenopleiders onder de loep: de ontwikkeling van een beroepsprofiel voor lerarenopleiders en het effect van het kennisnemen daarvan op hun zelfdiagnose (Focusing on teacher educators: the development of a professional profile for teacher educators and its effect on their self-diagnosis). Dissertatie. Universiteit Utrecht, Utrecht.

Koster, B. - Dengerink, J. (2001): Towards a Professional Standard for Dutch Teacher Educators. European Journal of Teacher Education, 24 (3), 343-354.

Koster, B. - Brekelmans, M. - Korthagen, F. - Wubbels, T. (2005): Quality requirements for teacher educators. Teaching and Teacher Education 21, 157-176.

Loughran, J. (ed.) (2005): The Missing Links in Teacher Education Design: Developing a Multi-linked Conceptual Framework, Springer, Dordrecht The Netherlands.

Lunenberg, M. - Korthagen, F. - Swennen, A. (2007): The teacher educator as a role model, Teaching and Teacher Education, 23, 586-601.

Lunenberg, M. - Dengerink, J. - Korthagen, F. (2013): Het beroep lerarenopleider. Reviewstudie in opdracht van NWO/PROO (Teacher Educator as a profession. Review). Amsterdam, Vrije Universiteit.

Maandag, D. - Deinum, J. - Hofman, A. - Buitink, J. (2007): Teacher education in schools: an international comparison. European Journal of Teacher Education 30 (2), 151-173.

Melief, K. (2009a): Rapportage Vooronderzoek; Leerkracht van Lerarenopleiders; herziening beroepsstandaard en registratie. (Reporting on a preliminary study; 'Teacher of teacher educators; revising the professional standard and registration'). Eindhoven, VELON.

Melief, K. (2009b): Projectplan Leerkracht van Lerarenopleiders (Project plan Teacher of Teacher educators). Eindhoven, VELON.

Meriënboer, J. van - Klink, M. v.d. - Hendriks, M. (2002): Competenties: van complicaties tot compromis. Een studie in opdracht van de onderwijsraad (Competencies: from 
complications to compromise. A study ordered by the Dutch Education Council). Den Haag: Onderwijsraad.

Murray, J. - Male, T. (2005): Becoming a teacher educator: evidence from the field. Teaching and Teacher Education, 21 (2), 125-142.

Murray. J. - Swennen, A. - Shagrir, L. (2009): Understanding teacher educators' work and identities: Becoming a teacher educator. Theory and Practice for Teacher Educators. 29-43.

Peer Learning Activity (2010): The Profession of Teacher Educator in Europe, Iceland.

Royal College (2005): CanMeds 2005 Framework. Retrieved April 14, 2012 from: http://www.royalcollege.ca/shared/documents/canmeds/the_7_canmeds_roles_e.pdf

Smith, K. (2003): So, What about the professional knowledge of teacher educators? European Journal of Teacher Education, 26 (2), 201-215.

Smith, K. (2005): Teacher educators' expertise: What do novice teachers and teacher educators say? Teaching and Teacher Education, 21, 177-192.

Snoek, M. - Swennen, A. - Valk, J. de (eds.) (2006) Teachers and their Educators Standards for Development; Proceedings of the 30th Annual Conference ATEE, Amsterdam 22-26 October 2005. Amsterdam, Hogeschool van Amsterdam.

Snoek, M. - Swennen, A. - Klink, M. van der (2011): The quality of teacher educators in the European policy debate: actions and measures to improve the professionalism of teacher educators. Professional Development in Education, 37 (5), 651-664.

Swennen, A. (2012): Van oppermeesters tot docenten hoger onderwijs: de ontwikkeling van het beroep en de identiteit van lerarenopleiders (From top-teachers to teachers in higher education: the development of the profession and identity of teacher educators). Dissertatie. Vrije Universiteit, Amsterdam.

VELOV (2012): Ontwikkelingsprofiel Vlaamse Lerarenopleider (Developmental profile Flemish Teacher educator). Leuven: Katholieke Universiteit Leuven.

Velzen, C. van - Volman, M. (2009): The activities of a school-based teacher educator: A theoretical and empirical exploration. European Journal of Teacher Education, 32 (4), $345-367$. 


\section{FÜGGELÉK}

\section{Tanárképzők szakmai sztenderdjei}

VELON (Holland Tanárképzök Egyesülete), 2012

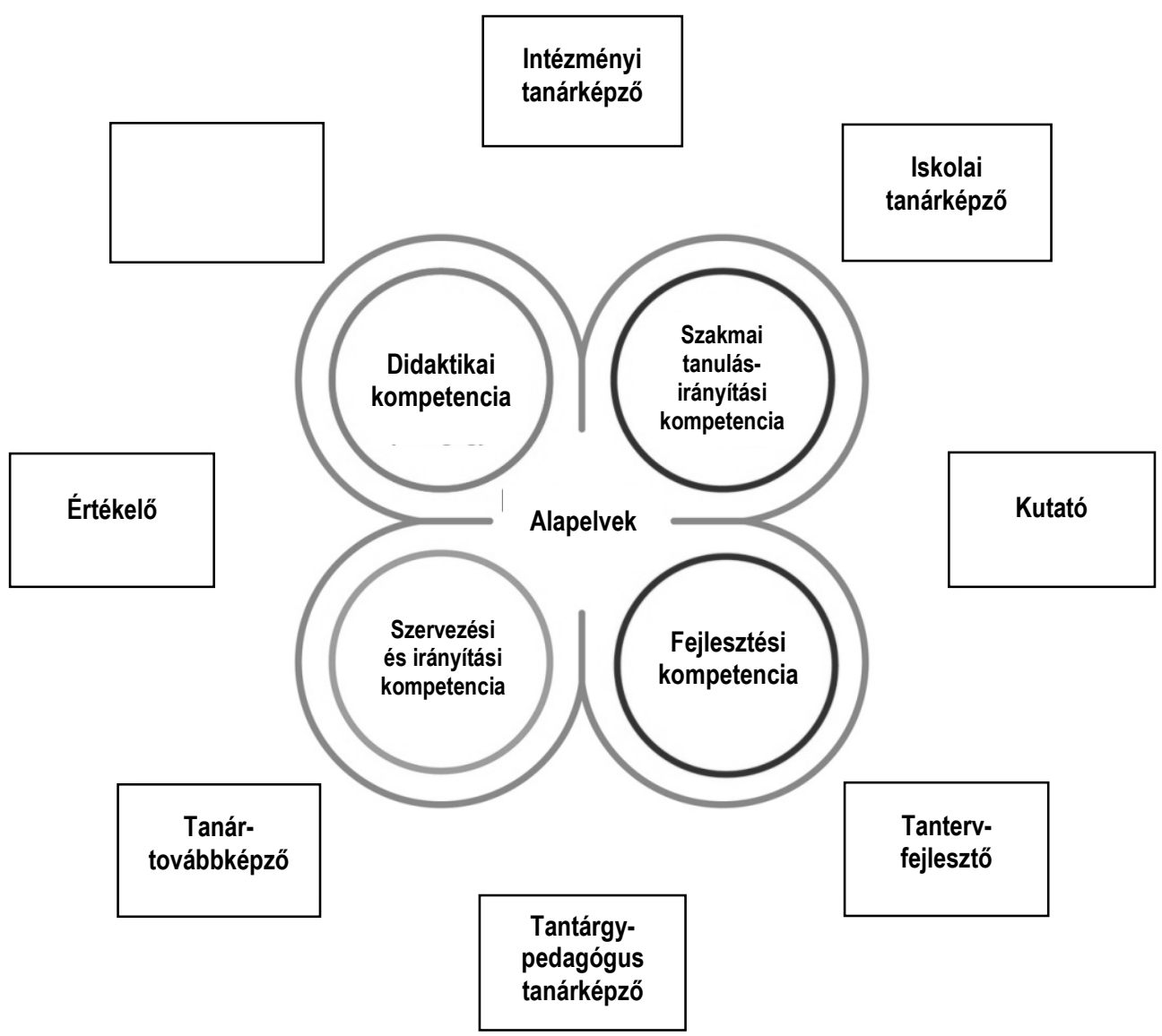




\section{Tanárképzők szakmai sztenderdjei}

A „Tanárképzők szakmai sztenderdjei” a közepesen tapasztalt tanárképző tevékenységét írják le.

Az intézményi tanárképző föiskolán vagy egyetemen, az iskolai tanárképző gyakorlóiskolában dolgozik.

Mindkettő oktathat általános iskolai, középiskolai vagy szakiskolai tanárjelölteket.

A szakmai sztenderdeken belül megkülönböztetjük (1) a szakma alapelveit és (2) a négy kompetenciaterületet. Ezen kívül megkülönböztetünk bizonyos nézőpontokat. Az utóbbiak körülveszik a szakmai sztenderdeket. Azt jelzik, hogy a tanárképző szakmai tapasztalata befolyásolja, hogy hogyan értelmezi a sztenderdeket. A nézőpontok kívül esnek a szakmai sztenderdeken.

\section{Az alapelvek}

A szakmai sztenderdek alapelvei a tanárképző szakmai munkájának alapját alkotják. Az alapelvekben a tanárképzői mesterség három alapeleme fejeződik ki: a tanulók tanulása, a tanár(jelöltek) tanulása és magának a tanárképzőnek a tanulása. Jellemző, hogy a tanárképző követendő mintaként müködik. Az alapelvek utolsó része a tanárképzési tudásbázis ${ }^{17}$ területeire utal.

\section{A kompetenciaterületek}

A kompetenciaterületek azt írják le, hogy a tanárképzőnek mire kell képesnek lennie ahhoz, hogy a gyakorlatban szakszerüen tevékenykedjen. Mindegyik kompetenciaterület tartalmaz egy rövid leírást, és mindegyik további három-négy részterületet foglal magába, a hozzájuk tartozó viselkedési indikátorokkal együtt. Ahol lehetséges, az indikátorok a kompetenciaterület leírásának megfelelően vannak osztályozva. Együttesen a tanárképző viselkedési repertoárjáról adnak képet. Ezenkívül minden egyes kompetenciaterület tartalmaz utalásokat a tanárképzők tudásbázisában található releváns forrásokra.

\footnotetext{
${ }^{17}$ Tanárképzők tudásbázisa: www.kennisbasislerarenopleiders.nl
} 


\section{Az alapelvek}

A tanárképző (leendő) tanárokat oktat: sajátos mintaadó szerepe van, amelyet konkrét módon alkalmazhat. Nyílt és átlátható módon képes modellálni a három alapelemet: a tanulók tanulását, a (leendő) tanárok tanulását és a saját tanulását. Figyelmét a (leendő) tanárok személyes és szakmai fejlesztésére és - ebből következően - a tanulók fejlesztésére összpontosítja. A tanárképző elkötelezett, megfelelő tudással és képességekkel rendelkező tanár. Motiválóan hat tanítványaira, innovatív, és érdekli mind az oktatás, mind pedig azok, akik abban munkatársként vagy tanulóként részt vesznek. Tudatában van a (leendő) tanárok, tanulók, a társadalom és saját maga iránti felelősségének. Képes saját szakmáját elhelyezni az oktatás társadalmi kontextusán belül. Tisztában van a tanításra és oktatásra vonatkozó nézeteivel, és ezeket szilárd alapokra helyezi. Nyílt és megbízható.

A tanárképző birtokában van a tanulásra, képzésre és tanításra vonatkozó releváns (tudományos) ismereteknek, iskolai és tanárképzési környezet (első- és másodrendủ pedagógia) tekintetében egyaránt. Tanítási tapasztalaton alapuló gyakorlati bölcsességgel rendelkezik.

A tanárképző tudatában van saját értékrendjének, normáinak és oktatási nézeteinek. Irányítja és figyelemmel kíséri a (leendő) tanárok és - közvetve - a tanulók morális fejlődését. Arra ösztönzi a (leendő) tanárokat, hogy alakítsák ki saját nézeteiket és értékrendjüket. Tiszteletben tartja a kulturális és ideológiai különbözőségeket.

A tanárképző vállalja a ráeső felelősséget az iskolai és intézményi tanárképzők és oktatók multidiszciplináris teamjén belül a (leendő) tanárok képzéséért és oktatásáért. Képes összekapcsolni az iskolai és intézményi képzési gyakorlatot.

A tanárképzőt kételkedő attitüd jellemzi. Tájékozott a saját tárgyával kapcsolatban folyó kutatások felől, és ismeri a megfelelő kutatási módszereket. A (gyakorlati) kutatásirányítási munkájában képes egészséges egyensúlyt teremteni a támogatás és kritika között.

A tanárképző képes a reflexióra. Kritikusan és konstruktív módon reflektál saját és mások fejlődésére, és képes a fejlődés irányítására. Ismeri saját szakmai erősségeit és gyengeségeit. Képes saját tevékenységének értékelésére a négy kompetenciaterület - a didaktika, a szakmai tanulás irányítása, a szervezés és irányítás, valamint az (ön)fejlesztés irányítása - alapján. 
A tanárképzö cselekvéseit a vonatkozó (tudományos) forrásokban fellelhetö ismeretekre alapozza...

\section{A tudásbázis területei}

A tanárképzési professzió

A tanárképzés pedagógiája

A tanulás és a tanulók

Tanítás és szupervízió

Speciális területek

Bővülő területek

\section{Didaktikai kompetencia}

\section{A tanárképzö didaktikai kompetenciával rendelkezik}

A tanárképző képes áttekinteni a releváns tanulási tartalmakat. Különféle didaktikai módszerek felhasználásával strukturálja a (leendő) tanárok tanulási folyamatait. Érdeklődik a didaktika új fejleményei iránt. Képes az új médiumokat úgy alkalmazni, hogy azok a tanulásban hozzáadott értéket eredményezzenek.

A tanárképző tudatában van annak, hogy tevékenysége mintaként szolgál a jelöltek számára. Munkája közben szem előtt tartja a saját magának mint tanárnak a pedagógiai viselkedéséről, a (leendő) tanárok pedagógiai viselkedéséről, a (leendő) tanárok tanulásáról és az ő tanulóik tanulásáról alkotott képét. Kinyilvánítja, világossá teszi és meg is tudja magyarázni didaktikai döntéseit és a tanításról alkotott nézeteit.

A tanárképző támogatja az elmélet és a gyakorlat közötti interakciót. Segíti a (leendő) tanárokat abban, hogy elmélyítsék és bővítsék tapasztalati tanulásukat, és hogy az elméletet is fel tudják használni akkor, amikor magyarázatot adnak tapasztalataikra. Ösztönzi és támogatja a (leendő) tanárokat saját tanítási gyakorlatuk szisztematikus elemzésében és értékelésében.

A tanárképző megbízható, megalapozott és átlátható módon értékeli a (leendő) tanárok fejlődését. Nyílt azzal kapcsolatban, ahogyan kollégáival együtt értékeli a (leendő) tanárokat. 
A didaktikailag kompetens tanárképzö jellemzöi:

\begin{tabular}{|l|l|l|l|}
\hline $\begin{array}{l}\text { A (leendő) tanárok } \\
\text { tanulási } \\
\text { folyamatainak } \\
\text { strukturálása }\end{array}$ & $\begin{array}{l}\text { Mintaadáson } \\
\text { alapuló oktatás } \\
\text { és képzés }\end{array}$ & $\begin{array}{l}\text { Az elmélet és } \\
\text { a gyakorlat közötti } \\
\text { interakció } \\
\text { támogatása }\end{array}$ & $\begin{array}{l}\text { A (leendő) tanárok } \\
\text { fejlödésének } \\
\text { értékelése }\end{array}$ \\
\hline
\end{tabular}

A gyakorlatban ez azt jelenti például, hogy...

\begin{tabular}{|c|c|c|c|}
\hline $\begin{array}{l}\text { A tanárképző } \\
\text { kiválasztja a releváns } \\
\text { tanulási tartalmat. } \\
\text { A tanárképző } \\
\text { különböző didaktikai } \\
\text { megközelítéseket } \\
\text { alkalmaz a (leendő) } \\
\text { tanárok tanulási } \\
\text { folyamatainak } \\
\text { strukturálásában. } \\
\text { A tanárképző } \\
\text { különböző digitális } \\
\text { oktatási módszereket } \\
\text { és technikákat (is) } \\
\text { alkalmaz. } \\
\text { A tanárképző kifejezi } \\
\text { érdeklődését } \\
\text { a (leendő) tanárok } \\
\text { tanulása iránt. } \\
\text { A tanárképzö } \\
\text { figyelembe veszi } \\
\text { a (leendő) tanárok } \\
\text { eltérő érdeklődési } \\
\text { körét. } \\
\text { A tanárképző segíti } \\
\text { a (leendő) tanárokat } \\
\text { saját tanulási céljaik } \\
\text { meghatározásában. }\end{array}$ & $\begin{array}{l}\text { A tanárképző } \\
\text { megmagyarázza, hogy } \\
\text { a saját tevékenysége } \\
\text { hogyan szolgál } \\
\text { mintául a (leendő) } \\
\text { tanárok számára. } \\
\text { A tanárképző } \\
\text { összekapcsolja saját } \\
\text { pedagógiáját a tanulók } \\
\text { tanításával. } \\
\text { A tanárképző } \\
\text { magyarázatot tud adni } \\
\text { didaktikai döntéseire. } \\
\text { A tanárképző az } \\
\text { oktatási program } \\
\text { konkrét kontextusába } \\
\text { ágyazott magyarázatot } \\
\text { tud adni saját } \\
\text { tevékenységeire. } \\
\text { A tanárképző elméleti } \\
\text { fogalmak és } \\
\text { meggondolások } \\
\text { felhasználásával képes } \\
\text { alátámasztani és } \\
\text { megmagyarázni } \\
\text { képzési tevékenységét. }\end{array}$ & $\begin{array}{l}\text { A tanárképzö } \\
\text { irányítja } \\
\text { a (leendő) } \\
\text { tanárok } \\
\text { tapasztalati } \\
\text { tanulásának } \\
\text { elmélyítését. } \\
\text { A tanárképző } \\
\text { segíti } \\
\text { a résztvevőket, } \\
\text { hogy elméleti } \\
\text { nézőpontok } \\
\text { igénybevételével } \\
\text { is értelmezzék } \\
\text { és alátámasszák } \\
\text { tanítási } \\
\text { gyakorlatukat. } \\
\text { A tanárképzö } \\
\text { a (leendő) } \\
\text { tanárokkal } \\
\text { együtt } \\
\text { általánosítja } \\
\text { az egy adott } \\
\text { kontextusban } \\
\text { nyert tudást. } \\
\text { A tanárképző } \\
\text { irányítja } \\
\text { a hallgatók } \\
\text { gyakorlati } \\
\text { kutatómunkáját. }\end{array}$ & $\begin{array}{l}\text { A tanárképző } \\
\text { összekapcsolja } \\
\text { az értékelést } \\
\text { a tanítási célokkal. } \\
\text { A tanárképző } \\
\text { különböző } \\
\text { adatokra mint } \\
\text { bizonyítékokra } \\
\text { támaszkodik az } \\
\text { értékelés során. } \\
\text { A tanárképző } \\
\text { átlátható és } \\
\text { verifikálható } \\
\text { értékelési eljárást } \\
\text { alkalmaz. } \\
\text { A tanárképző } \\
\text { összehangolja } \\
\text { értékelését } \\
\text { a kollégáival. } \\
\\
\text { A tanárképző } \\
\text { magyarázattal } \\
\text { szolgál a (leendő) } \\
\text { tanárok számára } \\
\text { értékelési } \\
\text { eljárására, az } \\
\text { értékelési célokra } \\
\text { és az értékelés } \\
\text { eszközeire } \\
\text { vonatkozóan. }\end{array}$ \\
\hline
\end{tabular}


A tanárképzö cselekvéseit a vonatkozó (tudományos) forrásokban fellelhetö ismeretekre alapozza...

\section{Lehetséges irányított kérdések a tudásbázisból}

Milyen didaktikai megközelítések léteznek?

Milyen elveket lehet megkülönböztetni?

Milyen oktatási módszerek állnak rendelkezésre?

Mi valójában a tanulás?

Hogyan megy végbe a tanulás szakmai kontextusban?

Milyen pedagógiai elveket lehet megkülönböztetni?

Miért kutassa az ember a saját gyakorlati munkáját? Mit jelent a gyakorlat kutatása?

Mi a szupervízió?

Mikor mondhatjuk, hogy valaki megtanult valamit?

\section{A szakmai tanulás irányításának kompetenciája}

A tanárképzö rendelkezik a szakmai tanulás irányításának kompetenciájával

A tanárképző tudja, hogyan alakítson ki egy biztonságos, de kihívásokkal is szolgáló tanulási légkört úgy, hogy eközben ő maga a modell szerepét tölti be. Fejlett interperszonális készségekkel rendelkezik. Elősegíti saját maga és a (leendő) tanárok közötti, illetve a (leendő) tanárok egymás közötti interakcióját, új médiumok használatával is. Képes összekapcsolni saját cselekvéseit a (leendő) tanárok tanítási cselekvéseivel.

Saját tanításában a tanárképző figyelembe veszi, hogy a (leendő) tanárok heterogén csoportot alkotnak, amelyben egyaránt vannak fiatal felnőttek és felnőtt tanulók (részidős és másoddiplomás tanárok). Felismeri és azonosítja a (leendő) tanárok aggodalmait, és olyan feltételeket igyekszik teremteni, amelyek elösegítik fejlödésüket. Saját modellszerepére alapozva képes tanulási lehetőségekként kiaknázni a (leendő) tanárok közötti különbségeket. 
A tanárképző a (leendő) tanárok munkájának irányításában figyel arra, hogy fejlödjön szakmai identitásuk. Reflexióra ösztönzi a (leendő) tanárokat, és arra, hogy vegyék kezükbe a saját tanulási folyamatuk vezérlését. Eközben segíti őket abban, hogy lefektessék az egész életen át tartó tanulásuk alapjait. E cél érdekében irányítja a (leendő) tanárok reflexióra való képességének és tanulási attitüdjének fejlődését.

A szakmai tanulás irányitása tekintetében kompetens tanárképzö cselekvéseinek jellemzöi:

\begin{tabular}{|l|l|l|}
\hline $\begin{array}{l}\text { Személyközi } \\
\text { interakció }\end{array}$ & $\begin{array}{l}\text { A változatosság } \\
\text { kezelése }\end{array}$ & $\begin{array}{l}\text { A szakmai identitás } \\
\text { fejlödésének irányítása }\end{array}$ \\
\hline
\end{tabular}

A gyakorlatban ez azt jelenti például, hogy...

\begin{tabular}{|c|c|c|}
\hline $\begin{array}{l}\text { A tanárképző a saját tanári } \\
\text { munkája során a (leendö) } \\
\text { tanárokban már meglévő } \\
\text { minőségekből indul ki. } \\
\text { A tanárképző lehetőséget } \\
\text { ad arra, hogy az inputot } \\
\text { a (leendő) tanárok } \\
\text { szolgáltassák. } \\
\text { A tanárképző arra ösztönzi } \\
\text { a (leendő) tanárokat, hogy } \\
\text { tanuljanak egymástól. } \\
\text { A tanárképző } \\
\text { megmagyarázza az } \\
\text { interperszonális } \\
\text { folyamatokat. } \\
\text { A tanárképző irányítja is } \\
\text { az interperszonális } \\
\text { folyamatokat. }\end{array}$ & $\begin{array}{l}\text { A tanárképző a (leendő) } \\
\text { tanárok csoportján belüli } \\
\text { változatosságot tanulási } \\
\text { lehetőségként kezeli. } \\
\text { A tanárképző differenciál } \\
\text { kor és tapasztalat szerint. } \\
\text { A tanárképző illeszkedik } \\
\text { a (leendö) tanárok tanulási } \\
\text { szükségleteihez. } \\
\text { Kulturális, szociális és } \\
\text { erkölcsi értelemben } \\
\text { a tanárképző } \\
\text { viselkedésében } \\
\text { alkalmazkodik a (leendő) } \\
\text { tanárok egyediségéhez. }\end{array}$ & $\begin{array}{l}\text { A tanárképző értelmezi } \\
\text { a (leendő) tanárok tanulásra } \\
\text { irányuló kérdéseit. } \\
\text { A tanárképző a (leendő) } \\
\text { tanárokat felelősnek tartja } \\
\text { saját tanulásukért. } \\
\text { Új nézőpontok } \\
\text { bevezetésével a tanárképző } \\
\text { elmélyíti a (leendő) tanárok } \\
\text { saját tanulásukra vonatkozó } \\
\text { reflexióit. } \\
\text { A tanárképző kontrasztba } \\
\text { állítja a (leendő) tanárok } \\
\text { egyéni fejlődését a tanári } \\
\text { szakma követelményeivel. } \\
\text { A tanárképző konkrét } \\
\text { visszacsatolást ad. } \\
\text { A tanárképző huzamos } \\
\text { időn át figyelemmel kíséri } \\
\text { a (leendő) tanárok fejlődését. }\end{array}$ \\
\hline
\end{tabular}


A szakmai tanulás irányitásában kompetens tanárképzö cselekvéseit a vonatkozó (tudományos) forrásokban fellelhetö ismeretekre alapozza...

\section{Lehetséges irányított kérdések a tudásbázisból}

$\checkmark$ Hogyan müködik a kölcsönös együttműködésen alapuló tanulás?

$\checkmark$ Mi a heterogenitás jelentősége a tanulásra nézve?

$\checkmark$ Hogyan lehet kezelni a kor- és tapasztalatbeli különbségeket?

$\checkmark$ Mi valójában a tanulás?

$\checkmark$ Hogyan megy végbe a tanulás szakmai környezetben?

$\checkmark$ Mikor hatékony a tanítás?

$\checkmark$ Mi a szupervízió?

$\checkmark$ Mikor mondhatjuk, hogy valaki megtanult valamit?

\section{Szervezési és irányítási kompetencia}

A tanárképzö rendelkezik a (leendö) tanárok oktatásával kapcsolatos szervezési és irányitási kompetenciával.

A tanárképző a megosztott (iskolai és intézményi) oktatás egyik aktívszereplöje. Támogatja a (leendő) tanárokat abban, hogy optimálisan megszervezzék saját tanulásuk terét. Összhangot teremt a (leendő) tanárok különböző tanulási környezetei között.

A tanárképző tisztában van a ráeső felelősséggel az iskolai és intézményi tanárképzők és oktatók multidiszciplináris teamjén belül a (leendő) tanárok képzésében és oktatásában. Ebben az összefüggésben figyelme kiterjed minden szereplő tanulására.

A tanárképző törekszik arra, hogy optimálisan megszervezze az iskolai tanárképzők és az intézményi tanárképzők által használt tartalmak összehangolását. Intézményének vezetésével szemben vitapartner.

A tanárképző hozzájárul a hatékony és ösztönző tanulási környezet kialakításához és fejlesztéséhez. A szakmai szituációkban történő tanulásról alkotott nézeteit és elképzeléseit megosztja a szakmai közösség tagjaival. 
A szervezési és irányitási kompetenciával rendelkezö tanárképzö müködésének jellemzöi:

\begin{tabular}{|l|l|l|l|}
\hline $\begin{array}{l}\text { A megosztott } \\
\text { oktatás } \\
\text { strukturálása }\end{array}$ & $\begin{array}{l}\text { Multidiszciplináris } \\
\text { team tagjaként } \\
\text { végzett munka }\end{array}$ & $\begin{array}{l}\text { Hozzájárulás } \\
\text { a tanárképzés } \\
\text { megszervezéséhez }\end{array}$ & $\begin{array}{l}\text { Hozzájárulás } \\
\text { a tanárképzés } \\
\text { irányításához }\end{array}$ \\
\hline
\end{tabular}

A gyakorlatban ez azt jelenti például, hogy...

\begin{tabular}{|c|c|c|c|}
\hline $\begin{array}{l}\text { A tanárképző } \\
\text { különböző (elméletileg } \\
\text { megalapozott) } \\
\text { nézőpontokból } \\
\text { megkülönbözteti } \\
\text { a megosztott oktatással } \\
\text { kapcsolatos } \\
\text { fejleményeket. } \\
\text { A tanárképző } \\
\text { hozzájárul az iskola } \\
\text { és az intézmény által } \\
\text { a leendő tanárok } \\
\text { számára biztosított } \\
\text { erős támogató rendszer } \\
\text { kialakításához. } \\
\text { A tanárképző } \\
\text { megszervezi a (leendő) } \\
\text { tanárok tanulási } \\
\text { környezetét. } \\
\text { A tanárképző } \\
\text { megfelelő összhangot } \\
\text { teremt az iskola és } \\
\text { az intézmény között } \\
\text { a (leendő) tanárok } \\
\text { tanulása tekintetében. } \\
\text { A tanárképző támogatja } \\
\text { a (leendő) tanárok } \\
\text { közötti együttmüködést. }\end{array}$ & $\begin{array}{l}\text { A tanárképzö } \\
\text { együttmüködik } \\
\text { a különböző } \\
\text { hatóságokkal, } \\
\text { amelyeknek } \\
\text { valamilyen } \\
\text { szerepük van } \\
\text { a tanárképzésben. } \\
\text { A tanárképző } \\
\text { nyíltan kommunikál } \\
\text { azokkal, akiknek } \\
\text { valamilyen } \\
\text { szerepük van } \\
\text { a (leendő) tanárok } \\
\text { tanulási } \\
\text { folyamataiban. } \\
\text { A tanárképző } \\
\text { tanácskozik } \\
\text { kollégáival } \\
\text { a különböző } \\
\text { körülmények között } \\
\text { folyó tanárképzésről. } \\
\text { A tanárképző } \\
\text { kinyilvánítja } \\
\text { a megosztott } \\
\text { tanárképzéssel } \\
\text { kapcsolatos nézeteit. }\end{array}$ & $\begin{array}{l}\text { A tanárképző olyan } \\
\text { tevékenységeket } \\
\text { szervez, amelyek } \\
\text { támogatják az iskola } \\
\text { és az intézmény } \\
\text { együttműködésében } \\
\text { megvalósuló } \\
\text { képzést. } \\
\text { A tanárképző } \\
\text { kiaknázza } \\
\text { a szervezetekben } \\
\text { rejlő lehetőségeket. } \\
\text { A tanárképző maga } \\
\text { is azok egyike, akik } \\
\text { megfelelő támogató } \\
\text { tanulási } \\
\text { lehetőségeket } \\
\text { biztosítanak. } \\
\text { A tanárképző részt } \\
\text { vesz az oktatás } \\
\text { minőségi } \\
\text { gondozásának } \\
\text { alakításában. }\end{array}$ & $\begin{array}{l}\text { A tanárképzö } \\
\text { aktívan részt } \\
\text { vesz a (leendő) } \\
\text { tanárok } \\
\text { oktatásáról } \\
\text { folytatott } \\
\text { diskurzusban. } \\
\text { A tanárképző } \\
\text { tanácskozik } \\
\text { a menedzsment } \\
\text { tagjaival } \\
\text { a (leendő) tanárok } \\
\text { oktatásáról. } \\
\text { A tanárképző } \\
\text { kezdeményezi } \\
\text { a kooperatív } \\
\text { tanulással } \\
\text { kapcsolatos } \\
\text { oktatáspolitika } \\
\text { kialakítását. } \\
\text { A tanárképző } \\
\text { csatlakozik } \\
\text { a tanárképzés } \\
\text { releváns } \\
\text { nemzet(köz)i } \\
\text { hálózataihoz. }\end{array}$ \\
\hline
\end{tabular}


A szervezési és irányitási kompetenciával rendelkezö tanárképzö cselekvéseit a vonatkozó (tudományos) forrásokban fellelhetö ismeretekre alapozza...

\section{Lehetséges irányított kérdések a tudásbázisból}

$\checkmark$ Milyen formában és szervezeti keretek között zajlik a tanárképzési intézmény és a partneriskolák közötti együttmüködés?

$\checkmark$ Hogyan megy végbe a tanulás szakmai környezetben?

$\checkmark$ Melyek a tanárképző intézményekkel kapcsolatos legújabb oktatáspolitikai fejlemények és tendenciák?

$\checkmark$ Milyen garanciák biztosítják a tanárképzés megfelelő színvonalát és minőségét?

$\checkmark$ Hogyan zajlik a minőséggondozás az oktatáson belül?

$\checkmark$ Milyen a tanárképzési programok belső szerkezete, és milyen szerep jut ebben a tanárképzőnek?

$\checkmark$ Hogyan épül fel a tanárképzés irányításának szerkezete?

\section{Fejlesztési kompetencia}

\section{A tanárképzö rendelkezik fejlesztési kompetenciával}

A tanárképző szisztematikusan értékeli saját tevékenységét. Ismeri erősségeit és gyengeségeit, és aktívan keresi a folyamatos tanulási lehetőségeket. Reflektál tapasztalataira és azok egyre mélyebb megértésére törekszik.

A tanárképző elemzően közelít saját munkájához. Kritikusan és különböző elméleti nézőpontokból követi az oktatás új fejleményeit. A tanárképzési tudásbázist és a (gyakorlati) kutatás más eredményeit felhasználva értelmezi és továbbfejleszti saját pedagógiai gyakorlati tevékenységét.

A tanárképző részt vesz a szakértelmének karbantartását és fejlesztését szolgáló tevékenységekben.

A fejlesztés tekintetében kompetens tanárképzö cselekvéseinek jellemzöi:

\begin{tabular}{|l|l|l|}
\hline Reflexió & Elemzés & $\begin{array}{l}\text { A szakértelem } \\
\text { karbantartása }\end{array}$ \\
\hline
\end{tabular}


A gyakorlatban ez azt jelenti például, hogy...

\begin{tabular}{|c|c|c|}
\hline $\begin{array}{l}\text { A tanárképző céltudatosan } \\
\text { és strukturáltan törekszik } \\
\text { saját tevékenységének } \\
\text { jobbítására. } \\
\text { A tanárképző különböző } \\
\text { adatforrásokat alkalmaz } \\
\text { saját tevékenységének } \\
\text { értékelése során. } \\
\text { A tanárképző adatokat } \\
\text { gyüjt az önértékeléséhez. } \\
\text { A tanárképző } \\
\text { szisztematikusan elemzi } \\
\text { saját tevékenységét. }\end{array}$ & $\begin{array}{l}\text { A tanárképző elemzi az } \\
\text { oktatásban és a társadalom } \\
\text { egészében mutatkozó új } \\
\text { fejleményeket. } \\
\text { A tanárképző saját } \\
\text { tevékenységének } \\
\text { tervezésekor felhasználja } \\
\text { a legújabb tanárképzési } \\
\text { szakirodalmat. } \\
\text { A tanárképző felhasználja } \\
\text { a tanárképzésre vonatkozó } \\
\text { (gyakorlati) kutatások } \\
\text { eredményeit, annak } \\
\text { érdekében, hogy javítsa } \\
\text { oktatómunkáját. } \\
\text { A tanárképző } \\
\text { szisztematikusan vizsgálja } \\
\text { saját tanítási gyakorlatát. }\end{array}$ & $\begin{array}{l}\text { A tanárképző karbantartja } \\
\text { tanárképzési tudását. } \\
\text { A tanárképző részt vesz } \\
\text { hazai és nemzetközi } \\
\text { tanárképzési szakmai } \\
\text { összejöveteleken és } \\
\text { konferenciákon. } \\
\text { A tanárképző kommunikál } \\
\text { hazai és külföldi } \\
\text { kollégáival a tanárképzés } \\
\text { minőségéről. } \\
\text { A tanárképző céltudatos } \\
\text { kutatással és } \\
\text { professzionalizációs } \\
\text { tevékenységekkel irányítja } \\
\text { saját fejlödését. }\end{array}$ \\
\hline
\end{tabular}

A fejlesztési kompetenciával rendelkezö tanárképzö cselekvéseit a vonatkozó (tudományos) forrásokban fellelhetö ismeretekre alapozza...

\section{Lehetséges irányított kérdések a tudásbázisból}

$\checkmark$ Melyek a tanárképzésre vonatkozó kutatás eredményei és termékei?

$\checkmark$ Melyek a tanárképzésre vonatkozó kutatás specifikumai?

$\checkmark$ Mire kell képesnek lennie, és mit kell tennie valakinek ahhoz, hogy a saját tevékenységét kutathassa?

$\checkmark$ Kinek a kutatásai és eredményei ezek?

$\checkmark$ Miért érdemes valakinek a saját tevékenységét vizsgálnia? Mi ennek a jelentősége?

$\checkmark$ Mit kell tennie a képzőnek folyamatos szakmai fejlődése érdekében? 


\section{Nézőpontok}

Az alapelveken és a négy kompetenciaterületen kívül különböző nézőpontok is kapcsolódnak a szakmai sztenderdekhez. A szakmai sztenderdek e nézőpontokkal való kiegészítése azt fejezi ki, hogy - tekintetbe véve a munkahelyi környezetet, a célcsoportot és/vagy a tantárgyi területet - a tanárképző konkrét munkaköre is befolyásolja tevékenységének módját. A nézőpontok kívül esnek a szakmai sztenderdeken. A tanárképzők dolgozhatnak tanárképzési intézményben, vagy a képző intézmény egy partneriskolájában, esetleg mind a két kontextusban. További nézőpontok is elképzelhetők. Az alábbi lista nem teljes.

\section{Intézményi tanárképző}

Az intézményi tanárképző (leendő) tanárokat oktat egy akkreditált felsőoktatási tanárképző intézményben. Az intézményi és iskolai tanárképzők együtt képzik a leendő tanárokat.

\section{Iskolai tanárképző}

Az iskolai tanárképző (leendő) tanárokat tanít gyakorlóiskolai környezetben. A gyakorlóiskola a megosztott tanárképzésnek megfelelően alakítja személyzeti politikáját. Az iskolai és intézményi tanárképzők közösen képzik a (leendö) tanárokat.

További nézőpontok:

\section{Kutató}

A kutató tanárképző kutatómunkát végez és irányít a tanárképzés területén. Ebből a célból támogatja például a (leendő) tanárok gyakorlati kutatómunkáját és/vagy hozzájárul a tanárképzés kutatással összefüggő tantervfejlesztéséhez. Tanárképzési kutatói és kutatásvezetői tevékenysége együttesen határozzák meg, hogy miként tekint a szakmai sztenderdekre. 


\section{Tantervfejlesztő}

A tantervfejlesztő tanárképző terveket készít és tanácsadást nyújt oktatási innovációkkal kapcsolatban. Ebből a célból például (digitális) tanulási környezetek létrehozására irányuló projekteket valósít meg és/vagy hozzájárul annak tisztázásához, hogy miként tekintenek szervezetének munkatársai az oktatásra. A tanárképzés innovatív pedagógiai eljárásainak fejlesztőjeként és tanácsadóként végzett tevékenysége együttesen határozzák meg, hogy miként tekint a szakmai sztenderdekre.

\section{Tantárgypedagógus tanárképző}

A tantárgypedagógus tanárképző a (leendő) tanárok tantárgy-specifikus gondolkodásának és cselekvéseinek támogatására irányuló oktatómunkát végez. Ebből a célból például figyelmet fordít a tanulók problématudatosságára, illetve céltudatosan dolgozik saját tartalmi tudásának és specifikus kompetenciáinak karbantartásán és bővítésén. A (leendő) tanárok tantárgy-specifikus gondolkodásának és cselekvéseinek támogatására irányuló tanítástervezöi tevékenységei együttesen határozzák meg, hogy miként tekint a szakmai sztenderdekre.

\section{Tanártovábbképző}

A tanárképző, illetve tanártovábbképző szakmai fejlesztő programokat tervez az (osztálytermi) gyakorlati munkából érkezők számára. Ebből a célból például összehangolja programkínálatát a továbbképzési igényekkel és/vagy továbbképzői hálózatot tart fenn az egész életen át tartó tanulásban és továbbképzésben érdekeltek részvételével. Tanártovábbképzői és programfejlesztői tevékenységei határozzák meg, hogy miként tekint a szakmai sztenderdekre.

\section{Értékelö}

A tanárképző mint értékelő értékeli a (leendő) tanárok szakmai kompetenciáit. Ebből a célból például értékeli a (digitális) tanulási környezetben készült anyagokat és/vagy megfigyeli és értékeli a (leendő) tanárok gyakorlati munkáját. A tanárképzőnek a szakmai kompetenciák értékelésével kapcsolatos tevékenységei együttesen határozzák meg, hogy miként tekint a szakmai sztenderdekre. 